\title{
The Cycle of Knowledge Creation and Learning in Agribusiness
}

\author{
Erlaine Binotto \\ Universidade Federal do Rio \\ Grande do Sul, Brazil and The \\ University of Queensland, \\ Australia
}

\section{erlaine@vortex.ufrgs.br}

Marina Keiko Nakayama

Universidade Federal do Rio Grande do Sul, Brazil

marina@ea.ufrgs.br

\author{
Eleri Hamer \\ Faculdade do Sul do Mato \\ Grosso, Brazil
}

professor@hamer.pro.br

Ricardo Azambuja Silveira Universidade Federal de Pelotas, Brazil 
implementation of new strategies and policies.

Competitiveness, flexibility and agility are key words in agribusiness organizations. These organizations should be preoccupied with reducing costs and improving the quality of their products and services. The competitive advantage among them appears, more and more, to lie in the quality of the services rendered by the people involved throughout the industry chain. Therefore, how these people learn is an important and strategic subject in a reality with permanent changes.

It is possible to observe great differences in the rates of adoption of change among Brazilian people linked to agribusiness; sometimes people are quick to change and others are slow. Change seems not to occur homogeneously because depends it on personal aspects such as background, learning style and capacity, adoption speed, amount of effort, economic resources, determination, degree of risk involved, among other factors.

To analyse the agricultural reality, it is necessary to understand how the evolutionary process is assimilated, comprehended and incorporated by agricultural producers and their collaborators or employees, with the aim of identifying and analysing the stages in the knowledge creation process by which they find answers to their problems, in order to implement changes.

The technological modernization of Brazilian agriculture has been influenced from two sides, the industrial producers of agricultural inputs and the agro-industry processors of the products from agricultural properties. In this new competitive environment, information, knowledge, and managerial skills and strategies can contribute to obtaining a competitive advantage for organizations in general, and the rural properties, in particular (Binotto, 2000). Blum (1999) is emphatic when it comes to the need of the professional development of farmers and he considers impossible for them to survive without transformations in their activities.

In this competitive context, it is necessary to understand knowledge as something essential for the success and the survival of organizations. The agricultural producers have a fundamental place as components and agents of change in the respective production chains, impelling them to review their technological, managerial and structural processes.

These changes which have occurred in agribusiness have caused many impacts on agricultural cooperatives which now face new threats and opportunities, for example, in internal as well as external markets. In this new context, it is necessary for co-operatives improve the management of all their available resources, tangible and intangible, to ensure their survival and their success in this new reality.

The central objective of this paper is to analyse the knowledge creation process in agricultural properties, at Co-operative Tritícola Mista Alto Jacuí Ltda, from the perspective of producers. The study is exploratory-descriptive and qualitative in character and it is based on the theoretical model of organizational knowledge creation of Nonaka and Takeuchi (1997), more specifically on their four modes of knowledge conversion.

The interest in analyzing the knowledge creation process in these rural properties is justified by the need to understand how agricultural producers learn and receive information, to identify the ways in which this happens and the learning relationships involved. This research can allow the organizations that develop programs for extension and diffusion of technologies, linked to processing and production, to define with greater clarity their strategies for intervention in educational processes. At the same time, this study aims to assess the importance of knowledge in the agribusiness sector, as well as the contributions that rural people can give to many segments involved in agribusiness such as government, centres of research, centres of extension, universities, cooperatives, industries and associations. 
Another reason to study knowledge in agribusiness is the lack of research in this area; most studies in the learning organization field to date have been focused in the organizational environment of private and public companies. In agribusiness, such studies are starting only slowly. In general, the studies have evidenced the importance of knowledge management, it being one of the richest resources in organizations and the importance of people who generate and are possessed of this important resource.

Therefore, this paper presents a theoretical referential the knowledge creation model of Nonaka and Takeuchi (1997), as well as organizational knowledge, organizational learning, agribusiness, Brazilian agribusiness and co-operatives. After that, it will describe the research method used, following by the description and analysis of the researched data and the final considerations.

\section{Literature Review}

\section{Organizational Knowledge}

In the new society, the traditional factors of production, land, capital and work are becoming secondary and they are being replaced by knowledge as the primary factor. Knowledge will be only productive when it is integrated into the performance of a task. This explains the purpose and the function of each organization in the knowledge society: to integrate specialized knowledge in a common task (Drucker, 1996).

The expression knowledge management was mentioned in 1975 (Goerl, 1975; Henry, 1975; McCaffery, 1975), along with the concept of the intellectual capital (Feiwel, 1975). Since then, the number of publications about knowledge management and intellectual capital has increased. One trend indicates that, by 2010 , there will be 10,000 such publications (Serenko \& Bontis, 2004).

Similarly, the interest in knowledge about learning has increased in recent years as well. Some authors consider that knowledge management and learning organization are the greatest sources of competitive advantage (Drucker, 1988; Kogut \& Zander, 1996; Prahalad \& Hamel, 1990; Starbuck, 1992). Other authors (Barney, 1986; Pawlowsky, 2001) have given emphasis to the cultural aspects in their analyses. Fiol and Lyles (1985), Bedeian (1986), Huber (1991) and Shrivastava (1983), consider the learning organization and knowledge so segmented, because they bring results that need more treatment to have applicability.

The importance of knowledge in the different levels and sectors of an organization tends to increase because it is the most important asset of the organization and it is the main ingredient that enables an organization to produce, make, buy and sell (Stewart, 1998). It is the greatest source of power and the key to change (Toffler, 1995). The result is that to find, stimulate, store, sell, share and manage this capital has become the most important economic task of individuals, companies and countries.

One reference to organizational knowledge describes it as an iceberg where explicit knowledge will be visible in the top, found out and shared easily, but the tacit knowledge is submerged and it is difficult to assimilate (Haldin-Herrgard, 2000). When it comes to explicit and tacit knowledge, it is important to acknowledge Polanyi (1967). He was the author who first developed the concepts of these sorts of knowledge.

Explicit knowledge can be described knowledge that is codified. It is knowledge transmissible by formal language, or it is systematic structured knowledge (Kim, 1993), classified in documents, practices and trainings (Rosemberg, 2001). It can be stored in routines, practices and procedures (Leroy \& Ramanantsoa, 1997) or it can be aggregated by a simple localization or logical deduction and formal study (Lam, 2000). 
For tacit knowledge, Polanyi (1967) uses the phrase "we can know more than we can tell", referring to the ability of people to know more than they can express by talk, because they know more than they can verbalize. Tacit knowledge cannot be totally communicated, but just perceived by individuals (Nelson \& Winter, 1982; Nonaka, 1994; Nonaka \& Takeuchi, 1997; Polanyi, 1967). It is difficult to codify (Leroy \& Ramanantsoa, 1997). This is a kind of knowledge that evolves a lot of subjectivity, intuition and hunches (Nonaka, 1991), as well as learning by doing (Lam, 2000) accumulated ability and experience (Leroy \& Ramanantsoa, 1997). It can be internalized through assimilation (Kim, 1993), observation, imitation and practice (Nonaka, 1991; Nonaka \& Takeuchi, 1997), experience and trial and error (Leroy \& Ramanantosa, 1997). Tacit knowledge seems to be very important in technological innovation processes (Howells, 1996) as a guarantee of competitiveness; indeed, some knowledge must remain tacit if an organization is to maintain a monopoly on a product.

Another important concept to present here is that of intellectual capital. Stewart (1998) considers intellectual capital as knowledge, information, intellectual property or experience that can be put in use to create wealth or something, which could possibly make somebody rich. To Reinhardt, Bornemann Pawlowsky, and Schneider (2001) intellectual capital is intangible and includes tacit aspects, but neither intellectual capital and nor intangible asset is comparable to knowledge. This cannot be interpreted as an object. To Edvinsson and Sullivan (1996) intellectual capital is a stock of information focused and organized which the organization can use for any productive activity or like source of competitive advantage. They also define it as knowledge can be converted into value and the knowledge companies as those commercialise the knowledge created by their human resources.

When it comes to comprehension of the term knowledge, Spender (2001), points out that knowledge as an object is that which someone can create or buy, similar to an immobile or any other organizational capital and susceptible to storage. However, knowledge as a process is that which focuses on knowledge creation with impact on the motivation and the creativity of the employees, aiming to take advantage of tacit knowledge involving individual and social processes of creation, motivation and communication. Knowledge as a process is a focus of this study.

To Davenport and Prusak (1998), knowledge is neither data nor information, although it is related to both and the differences among these terms are normally a question of degree. They point out the importance of knowing clearly which of them, knowledge, data and information the organization needs or makes use, as well as the utility of each one. They can contribute, in some cases, to establishing the success or the failure of the organization.

Bhatt (2001, p. 69) considers "the definition of data, information and knowledge is difficult". The subdivisions of the literature are found definitions of different degrees of complexity, and they are difficult to separate. This paper focuses on the following concepts: data, information and knowledge, aiming to differentiate them, for the purpose of this study, as follows:

Data - is a register or notes regarding a determinate event or occurrence. The database is a good example. To Davenport and Prusak (1998) the data are not capable of supplying judgement or interpretation, nor providing a reliable base for making decisions, because they describe just a part of the knowledge about the event or occurrence.

Information - consists of a group of data with a meaning that reduces the uncertainty regarding something or that improves the knowledge about it. Information is like a message or "like data that makes the difference" (Davenport \& Prusak, 1998, p.4). The information is a way or material necessary to extract and construct the knowledge" (Nonaka \& Takeuchi, 1997). 
Knowledge - to Davenport and Prusak (1998), knowledge is a flowing mixture of condensed experience, values, contextual information and insight experienced which provides a structure for evaluation and incorporation of new experiences and information.

To Leonard and Sensiper (1998) knowledge is information relevant, actionable and based, at least partially, on experience. Nonaka and Takeuchi (1997) consider that knowledge is essentially related to human acting. Davenport and Prusak (1998) contribute with this statement and consider that the knowledge exists inside people and it is part of complex something and unexpected of human act. Its origin and application are in experts minds. In the organizational context, it is use as being inside not only in documents or repositories, but also in routines, processes, practices and organizational norms. It develops over time through experience, embracing what people learn from courses, books and mentors and informal learning as well.

Nonaka and Takeuchi (1997) seem to establish, in their theory, a strong relation between new and old knowledge and structural and personal hierarchies among other correlations. Organizational knowledge creation depends on the capability of a company to create new knowledge, diffuse it throughout the organization as a whole and incorporate its use in products, services and systems.

There is a different way to share knowledge, a way described by Nonaka and Konno (1998); they consider knowledge embedded in $b a$ (shared spaces), where it is then acquired through one's own experience or reflection on the experience of others. This concept is also very important when considering knowledge, but the theoretical base to be used here will be the Nonaka and Takeuchi model.

\section{Organizational Knowledge Creation Model of Nonaka and Takeuchi}

To Marakas (1999 p. 440) "knowledge creation refers to the ability of an organization to develop novel knowledge and useful ideas and solutions". Nonaka and Konno (1998) created a model of knowledge creation, similar to that of Nonaka and Takeuchi (1997), named the SECI model, aiming to transfer tacit knowledge.

Nonaka and Takeuchi (1997) present a theoretical model about organizational knowledge creation based on case studies of Japanese companies with emphasis on the influence thereon of oriental philosophy, adopting as the central point the distinction between tacit and explicit knowledge. The same model is discussed in different papers (Nonaka, 1991, 1994; Nonaka \& Konno, 1998; Nonaka \& Reinmoeller, 2000; Nonaka, Reinmoeller, \& Senoo, 1998; Nonaka, Reinmoller, \& Toyama, 2001; Nonaka \& Takeuchi, 1997; Nonaka, Toyama, Byosiere, 2001; Nonaka, Toyama, \& Konno, 2000; Nonaka, Umemoto, \& Senoo, 1996).

To Nonaka and Takeuchi (1997), the secret to knowledge creation is in the mobilization and conversion of tacit knowledge. This way, they tell the existence of an epistemological dimension of knowledge creation, which circulates between tacit and explicit knowledge, and an ontological dimension concerned with the levels of the entities, which create of knowledge; these levels are the individual, group, organizational and interorganizational.

At the heart of this theory is the concept of the spiral of knowledge creation. To Nonaka and Takeuchi (1997, p. 62), “...the spiral appears when the interaction between tacit and explicit knowledge elevates dynamically from an inferior ontological level up to higher ones". The tacit knowledge is that perceived and internalised by people, whole codes, manuals, forms, numbers or patterns represent the explicit knowledge. These authors elaborated the distinction between the concepts of tacit knowledge and explicit knowledge, established by Michael Polanyi (1967), who was quoted before. He pointed out that all knowledge has a tacit dimension and it is accessed at an individual level. 


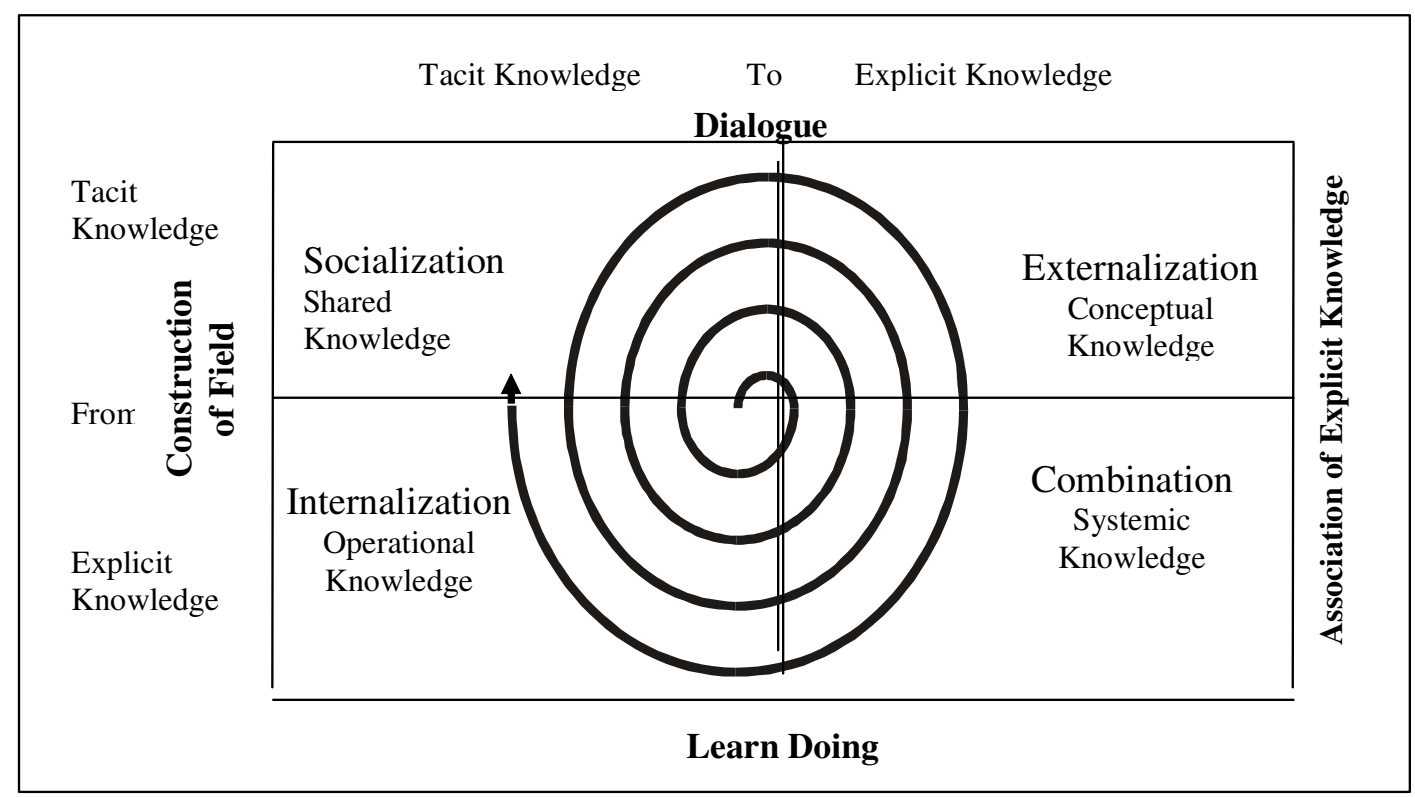

Figura 1- Content of Knowledge created by four models

Fonte: Nonaka \& Takeuchi (1997, p. 81)

The distinction between tacit and explicit knowledge, even if approached in different ways, does not exclude the need to understand they are parts of the same whole, functioning in the practice as an interactive process, complementing and constantly changing (Nonaka \& Takeuchi, 1997).

The motor of the knowledge creation process as a whole consists of four groups of conversion of knowledge, created from the interaction between tacit and explicit knowledge. They are the mechanisms through which the individual knowledge is articulated and amplified in the organization. The four modes of conversion and the content of knowledge, according to Nonaka and Takeuchi (1997), are represented in Figure 1.

Socialization - from tacit knowledge to tacit knowledge: it is centred on sharing experience among people, differentiated by ways, like observation, imitation and practice. However, it is important to emphasize the necessity of associated emotion associated and the specific conceptualisation of sharing.

Externalisation - from tacit knowledge to explicit knowledge: it is normally oriented by a metaphor and/or analogy and motivated by capability to express the content in the whole. It is the way, which aims to make explicit the knowledge of the people. It is a perfect knowledge creation process, inasmuch as the tacit knowledge becomes explicit, and it is expressed by way of metaphor, analogies, concepts, hypotheses or models.

Combination - from explicit knowledge to explicit knowledge: in this way, the change and combination of knowledge occurs through ways such as documents, meetings, chats on the phone or nets of computerized communication of explicit knowledge, considering other groups of explicit knowledge.

Internalisation - from explicit knowledge to tacit knowledge: this represents the incorporation by the individual from explicit to tacit knowledge. It is used in trainings, courses and manuals. In this sense, so that the knowledge becomes tacit, the verbalization and diagram of it in the form of documents, manuals or oral history is necessary. The documentation helps people internalise their experiences, improving their tacit knowledge. Organizational knowledge creation is centred on 
people and their tacit knowledge. So, the organization needs to mobilize the tacit knowledge created and accumulated at the individual level.

Starkey (1997) considers that the creation of new ways of knowledge serves as a base and plays an important role only inasmuch as the organizations make it capable of being transformed into new technological advances, culminating in respective products and processes.

In this sense, to Binotto and Nakayama (2001), the adaptation that the organization seeks in order to face the changes will be occurring inasmuch as the people have new attitudes and new ways to act. Equally, Nonaka and Takeuchi (1997) show that knowledge creation involves the interaction between (i) the obtaining of know-how in order to solve specific problems based on existent premises and (ii) the establishment of new premises aiming to cancel those existent, which form a type of dynamic spiral.

In this way, the tacit knowledge passes from the individual level to transforming and converting continually, from person to person, groups, departments, organizations and interorganizations. Learning is included in this theory and it will be presented as follows.

\section{Organizational Learning}

Research into organizational learning was under represented in the literature regarding managerial studies for decades, being recognized with more interest in the last 10 years. These more recent studies have been driven by different perspectives and orientations. Most of them were addressed to the need to adapt to environmental variations, to learn from the past, to improve and to react to the environmental threats and to innovate permanently (Easterby-Smith \& Araujo, 1999).

Argyris (2000) considers that apart from the difficulties involved in investigating the question of learning, most of the companies have only a slight notion that this dilemma exists. The reason lies in their ignorance of their own concept of learning and of which way to achieve it. The effective learning does not refer to how people feel but how they think. Organizational learning is a process to detect and correct errors. The error is seen as a deviation between our intentions and what occurred in fact (Argyris, 1992). The same author offers the concepts of single loop, double loop and deutero learning to show the evolution of learning (Argyris, 2002; Argyris \& Schön, 1974).

Learning may be defined as any enthusiastic permanent change in the behaviour that happens as a result of experience. The learning can happen in a process where people behave in a specific way as a result of a learning that was "learned" in some phase of their lives. That is to say, it has happened if an individual behaves, reacts or answers as a result of experiences in a different way to the way he behaved before (Robbins, 1999).

To Senge (1999), the human being comes into the world motivated to learn, to explore and to try. Unfortunately, most of the institutions in our society are designed more to control than to learn. This author, one of the first theorist of the organizational learning, defines creative tension as the resulting force of people's natural tendency to look for a solution for found tensions, that is to say, creative tension produces natural energy to change the reality. People consider what they have, compare it to what could be, that is more important for them than that which currently is. The beginning of creative tension teaches us that a precise picture of the current reality is as important as an enthusiastic picture of the future that is desired (Senge, 1999). The same author presents the differences in learning among organizations and establishes five subjects to solve the difficulties and to enlarge the learning capabilities of organizations. They are: the personal domain, mental models, shared vision, learning in teams and systemic vision (Senge, 1999).

The studies of Kolb (1997) resulted in an inventory of the learning models. He developed own emphasis on the role of experience in the learning process considering the studies from the social psychologist Kurt Lewin. According to this model, learning would be a cycle that would require 
four abilities: 1. Capabilities in new experiences involving complete openness and impartially, the concrete experience (CE); 2. Reflection concerning the learner's experience and observation from several perspectives, the reflexive observation (RO); 3. Creation of concepts that interact with the observations in strong, logical theories, the abstract conception (AC); 4. The active experimentation (AE), that is the use of these theories to make decisions and solve problems.

Organizational learning involves not only the elaboration of new cognitive maps which make it possible to comprehend better what is occurring in the organizations in their external and internal environment, but also the definition of new behaviours that prove the effectiveness of learning. The organizational rules and procedures have as base the individual mental models that are shared by the group (Fleury \& Fleury, 2000).

Kim (1993) considers that organizational learning is something more complex and dynamic than a simple enlargement of individual learning. He points out that, when the environments of organizations change, the individual convictions about the environment also change; this defines a different group and organizational actions begin the learning cycle again. This way, the issue of transferring learning is developed through exchange of individual and shared mental models.

Swieringa and Wierdsma (1995) present learning as a competence, "learn to learn "and so that one can change as a demonstration of the learning. The condition for an organization to learn is through the learning of its members. However, that doesn't happen in an automatic way, when the individuals who are inside the organization learn something. This means that individual learning is necessary, but not sufficient condition for collective learning. Individual learning is important for the organization, but the organizational learning cannot simply be considered as the sum of the learning of its members (Fiol \& Lyles, 1985).

In Huysman's vision (2001), if the theories of an individual participant are not codified in organizational theories, the person learned, but the organization didn't. Then, in the adaptation of organizations to change, it can be considered that it will occur when the people that act in them have a new attitude in their approach to the work and a new form of acting. In this sense, the individual's development is the decisive factor for the learning, because attitude change is the result of learning.

Considering the relevant aspects to organizational learning, it is possible to realize that there is not one best way to improve the process; there may be many, and each case should be analysed in detail. The ways in which learning occurs depend on many aspects such as the actual situation and its particularities, sectors and activities.

\section{Agribusiness}

Two researchers of the Harvard University, John Davis and Ray Goldberg, in 1957, presented the agribusiness concept as being the sum of operations, stock, process and distribution of agricultural products and items produced them (Davis \& Golberg, 1957). These authors took an important initial step in attempting to treat agribusiness like a differentiated activity, with its own concepts and characteristics. All studies by Davis \& Goldberg are focused on the notion of systemic vision that goes from the agricultural producer to arrive at the distribution of final products.

This first definition of agribusiness has always made it possible to create others to explain the same phenomena that have occurred in the North American economy: the increased sectorial inter-relations among agriculture, industry and services. Davis and Goldberg (1957) said that the modern farmer has become a specialist who has had his operations reduced to growing plants and bringing up animals. Other activities have been transferred, for the most part, to outside the farm gate. Nowadays, the economy of agribusiness links, essentially, the functions that were done in agriculture 150 years ago (Silva, 1996). 
World agribusiness is a sector that has large increased in recent years. There are many differences and particularities among countries and regions when it comes to products, services and technologies. These can define the degree of competitiveness and success of a city, a region, and a country.

\section{Brazilian Agribusiness}

Brazilian agribusiness seems to be in a prime position to draw on its agricultural strengths and become a leader in exporting to niche markets around the world. Examples of its achievements are its recent world leadership in beef exportation, second place in soybean production and becoming one of the major producers and exporters of sugar.

Some economic information about Brazil would seem to be important, if the aim is to assess the importance of agribusiness. In 2003 the Total Gross Domestic Product (GDP) was 1.3 trillion dollars; exports in 2002 were worth US\$ 60.141 billions and in 2003, US\$ 66.3 billion dollars. Agribusiness was responsible for US\$ 30.639 billion worth of exports in 2003, 23.3\% more than 2002. It represented $41.9 \%$ of the national exports and its GDP was 420 billions dollars (32\% of Total GDP). The volume of grain in 2003 was 122.4 millions tonnes, 26.5\% bigger than in 2002 (Brazilian Ministry of Agriculture, n.d.). With the increase of this sector in the last decades, it has been responsible for positive results in the development of the country and in economic stability, as well as offering a significant number of new employment opportunities.

This increase in production and exports is the result of good conditions of climate, the use of new technology and good prices. This reality brings improvement and development in the whole productive chain - farmers, agro-industry, commercialization, exportation, as well as the improvement of the performance of the co-operative sector.

\section{Co-operatives}

History proves that cooperation has always existed in society, since ancestral times, probably associated with fights for survival and nowadays linked to economic, policy and social crises. In this way, co-operative action is inseparable from confuses itself with the history of humanity.

According to Hugon (1984), the utopian socialist thinking appears with the coming of industrialisation and it has as its main characteristics the pursuit of justice and fraternity with the targets of the economic way, social equality in organizations and the sharing of wealth.

The co-operatives in Brazil appeared in the end of the nineteenth century, motivated by the new socio-economic situation with the abolition of slavery. Forming co-operatives were a strategy used for survival for the poor, especially by unemployed workers in the Industrial Revolution. During the twentieth century it shows like a lever of economic efficiency, by economies of scale that it provides, by integration as horizontal as well as vertical levels, and of margin of profit as well.

In Brazil, it seems that the main tendencies in the thinking of two co-operatives were followed. The Rochdaleano, from the ending of the nineteenth century until the beginning of the 70s, and the Non-rochdaleano, from the end of the same decade, concerned how been since ancestral times about matching the promotion of economic solidarity with managerial rationalism rises.

Bialoskorski (1999) considers the co-operatives as enterprises that provide their associates or members (they are considered owners and users of services and they have the right power to vote in the pursuit of their common objectives) with bargaining power in imperfect markets, as well as the facilitation of the aggregation of value in the agricultural commodities. The author justifies possible the distribution of the results operations, motivated by the collective organization. 
It is relevant to highlight that the most important thing in the model of the co-operative organization is that the decisions about the economic activity and the results of the financial exercise (leftovers and losses) fit to the work (Lauschner, 1995).

In the last decade, the opening of markets, associated with other factors like the formation of economic blocks, among them Mercosul, have put great pressure on most of the agricultural cooperatives, an important segment in Brazilian agribusiness. Facing this pernicious context, many co-operatives need to adapt themselves to meet the challenges through a learning process, redefining rules, and addressing management of resources and efforts, mainly in areas that have to become more efficient.

Among the co-operatives that have assumed the professionalisation, it can be said that only a few, besides clear policies and search of speed in the adaptation to the changes, have been concerning about the development of their associates. These professionalisation programs include not only the supports to the technological processes, such as seeds, fertilizers as well as other inputs, but at the same time, and mainly, actions in the conduction of the business, centred in educational, managerial processes and that have improved the acting of their cooperated.

\section{Methodological Procedures}

This paper is an exploratory-descriptive study with qualitative data based on the theoretical model of knowledge creation of Nonaka and Takeuchi (1997). To Tripodi, Tony, and Meyer. (1975), exploratory-descriptive studies are those exploratory studies which aim at describing a phenomenon; the main preoccupation may be with a behavioural analysis and they are accomplished empirical and theoretical analyses.

It was used a sample of eleven farmers, composed of two groups of associates or partners from the co-operative Triticola Mista Alto Jacuí Ltda - Cotrijal. This co-operative was founded in 1957 in Não-Me-Toque city, Rio Grande do Sul State, Brazil, and it has approximately 850 employees and 3,200 associates. One of the groups ( 6 farmers) was composed of producers who take part in a management group named MG, using managerial tools with systematic assistance from Cotrijal. This sample was limited to those who integrate the program with three or more productive cycles or crops. The six producers from MG were chosen by chance from among 35 farmers who live in this city. Five farmers, external producers of the management group, named EMG, composed the other group. These producers were chosen from among other associates of the cooperative at the same place.

The sample included two groups, MG and EMG, considering that there were important differences between them. However, the information showed that the knowledge creation in two groups is very similar. The results of the two groups researched will be presented without distinctions.

The sample for the two groups was restricted to farmers who plant up to 200 hectares and had as their principal activity grain production (soybean, corn, wheat, oats and barley). It's important to note that the classification of the sample by exhaustion can explain the small number of farmers used in this research.

The instrument of research was a semi-structured interview. To analyse data was used content analysis, complemented by the available information and secondary data. Previously, to the effective research was used a survey with other six producers as a way to validate and adequate the instrument of the research, which brought good contributions to improve it. 


\section{Description and Analysis of Information}

The information obtained in the research was collated under the four categories of knowledge conversion described in the organizational knowledge creation model of Nonaka and Takeuchi (1997), as shown in Table 1.

\begin{tabular}{|c|c|}
\hline $\begin{array}{l}\text { Conversion } \\
\text { Modes }\end{array}$ & Research Information \\
\hline Socialization & $\begin{array}{l}\text { - There are differences associated to the environmental interaction among pro- } \\
\text { ducers; } \\
\text { - In family relationships, there is emotion associated with the sharing of ex- } \\
\text { periences; } \\
\text { - Trusting relationship with the group that they take part; } \\
\text { - Socialization occurs more frequently in the relationship groups; } \\
\text { - Observation occurs through accompaniment; } \\
\text { - Imitation occurs in the search for more knowledge, for example, in copying } \\
\text { of methods and procedures of other producers; } \\
\text { - Practice occurs through experimentation. }\end{array}$ \\
\hline Externalization & $\begin{array}{l}\text { - Knowledge isn't noticed as a discovery; } \\
\text { - New processes are evaluated with caution- there is the search for more in- } \\
\text { formation, experimentation and practical application; } \\
\text { - Dialogue and collective reflection are frequent, informal and without registra- } \\
\text { tions; } \\
\text { - Metaphor-it wasn't possible to identify clearly; } \\
\text { - Analogy- used quite often; } \\
\text { - Model- experimental and practical models. }\end{array}$ \\
\hline Combination & $\begin{array}{l}\text { - Intensive use of knowledge, with the influence of Cotrijal; } \\
\text { - Stimulus and accompaniment motivating the combination; } \\
\text { - Computer and internet still of potential use; } \\
\text { - Before making a decision, farmers search for more information and discuss } \\
\text { with the technicians; } \\
\text { - There is little understanding of the need of implanting the generated knowl- } \\
\text { edge; }\end{array}$ \\
\hline Internalization & $\begin{array}{l}\text { - Documentation and verbalization aren't explored very hunch; farmers just } \\
\text { react to the needs of the situation; } \\
\text { - Experimentation with making the change is the main aspect of internalisation } \\
\text { for these farmers (to learn doing); } \\
\text { - Technical recommendations and operational registrations aren't very much } \\
\text { used; } \\
\text { - Knowledge generated by the producers is based on the systematic experimen- } \\
\text { tation is recognized by other farmers. }\end{array}$ \\
\hline
\end{tabular}

Source: elaborated by authors through collected data

A significant change perceptible in the last few years is the more open nature of family relationships and receptiveness to the changes. This seemed to contribute to more experiences (experiments) being accomplished and more knowledge being generated. Another interesting aspect was the decreasing of the load of manual work, which was replaced by mechanized, lighter work, allowing space for the development of problem solving thinking about changes. It was demonstrated clearly in some declarations from farmers during the research. 
The development dichotomy among farmers seems to be influenced by the speed of changes and mainly by how they are adjusted and adopted in the properties by assimilating them. Blum (1999) emphatically affirms that the farmers who stay cloistered by themselves on their property and stop facing the transformations going on around them tend not to survive.

In general, the producers are conscious of the actual stage of development and the needs to continuity to improvement of work. There is not a unique or casual moment of transformation, but in several of actions throughout the history of the property coming from observation, adaptation and mainly attitudes, that stimulates the evolution of knowledge constantly and continuously.

During the research, it was realized that there are cases in which producers have available useful data referring to their properties and activities; however, they show significant difficulty to transform them into information. They do not always use them when making decision, and in addition, the systematisation and conversion of knowledge still seem a little common.

Nevertheless, for new knowledge to be created in the rural properties researched, at least three conditions should be considered essential: the first is associated with the people involved and the need for them to have a positive emotional feeling linked to the work and the property; the second refers to the of the property creating the interaction field, through good personal relationship with rules and clear policies, systematic planning, controls and discussion which stimulate the interpersonal relationships and the experimentation; and the last, the external incentives based, mainly, on formal trainings with alternation between theory and practice, such as field days, farm visits, discussions with neighbours, besides supervision and periodic technical controls, and analysis of the results.

Knowledge creation, according to the Nonaka and Takeuchi (1997) model, begins in knowledge socialization which has its central point in the sharing of experiences. It occurs through the people working together on the farm sharing their experiences. In this common place, the stimulus was created by the farmer in socializing the communication of information and the stimulated experimentation. This has created a suitable environment. But, these ways are relevant when there is a personal interest by farmers in the knowledge to be socialized; two conditions appear to be necessary for the socialization to occur with success: the emotion associated with the knowledge as already showed by the authors, and mainly, the personal attention to the work which was considered as fundamental practice, combined with the observation of the acquisition of tacit knowledge.

To Huysman (2001) it is necessary to consider both the individual participant and the organizational aspects, in order to understand how individual and organizational learning occur.

The externalisation of knowledge follows the integration process, which creates knowledge in rural properties. Certain stimuli are need for externalization or inspirations to occur and, in this case, are important ways the extreme observation of activities and tasks associated to the analogy. It's possible to realize that an analogy is required for externalisation occurs, because it is an impulse capable of activating an action in the collaborator. These normally have their origin in discussions among collaborators and neighbours, with technicians, in field days, lectures and seminars.

It develops in the actors responsible for the conduction of the business, abilities to solve problems, to try new technologies, to learn more from their experiences, to observe the behaviour of others and become capable of, besides learning, transmitting and sharing the knowledge with other people involved in the process.

Effectively, the conversion occurs from experimentation, elaboration of experimental models put into practice in small areas of the farm. After this, the knowledge converts into definitive mental 
models, being patterned inside the property and applied across the production. It occurs with and through new discussions in informal reunions or through individual analysis.

The combination of knowledge is used extensively; this was shown through simple ways such as specific trainings about the handling of plants and techniques of work with machines and equipment, field days, technical visits, besides several lectures. The results of learning generated with the technology from the experimentation of new technologies and procedures represent knowledge that will be combined with other sources.

The internalisation of knowledge occurs, mainly, through practice, in the experimentation and accompaniment of work. In essence, it means the implementation of changes in properties. It is influenced by other ways of knowledge conversion. The discussions or verbalizations about explicit knowledge, as well as from the operational registers used as controls and the written technical recommendations, which serve as planning, are also important ways that contribute to the internalisation of the knowledge.

In synthesis, although it is necessary to socialize the internalised knowledge so that it becomes it organizational knowledge, it could be seen that this practice does not necessarily occurs in a sequential way, according to the theory of Nonaka and Takeuchi (1997).

In a general way, the knowledge creation process on the properties studied appeared complex, dynamic and integrated, hindering its systematisation and modelling. The various modes of creation occur at the same time on a farm. It causes some differences between a model and other by specific characteristics of each one, where a specific model can manifest intensity to the detriment of others.

Considering group researched, it is possible to verify that, for the modes of knowledge conversion occur on agricultural properties there is the need to transit constantly from tacit to explicit knowledge according Nonaka and Takeuchi (1997) theory. It depends significantly on the methods that will be used to stimulate this transformation in their activities.

This way, this research assesses for understanding how mental models are changed, permitting the appearance of new models and proving the occurrence of new knowledge, once it needs to be internalised to occur.

The Interactive Cycle of Change in Mental Models illustrated in Figure 2 indicates this process.

The mental models or skills which the rural producers already are modified in an interactive process, mainly through analogy, discussion and experimentation, to construct a new mental model or new skill.

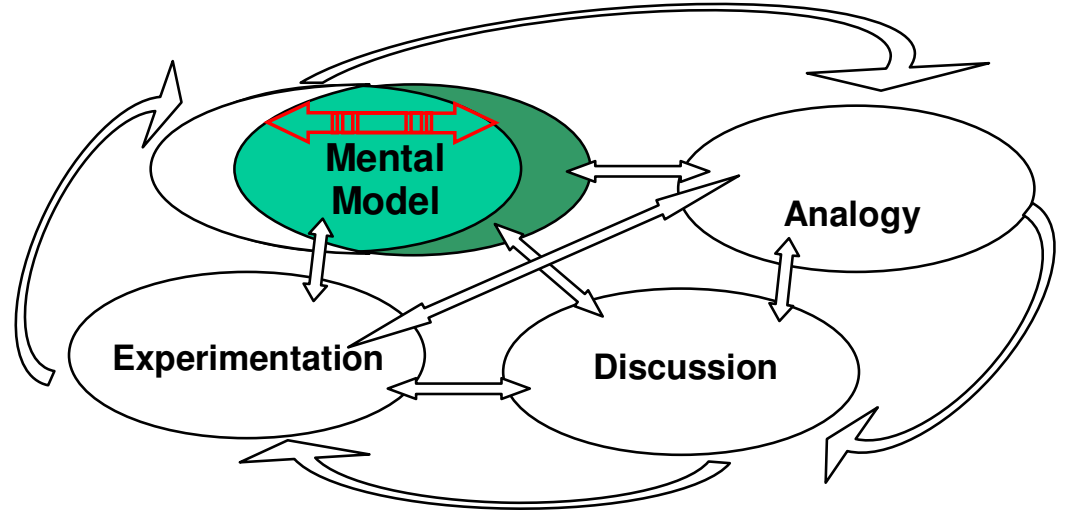

Figure 2: The Interactive Cycle of Mental Model Change

A universe of argu-

Source: Hamer, Binotto \& Nakayama (2003) ments, experiences and information has formed the existing mental model, when it receives a stimulus (either internal and/or external to the farm) and it has the capability to put in question its stability while model. It is dynamic, inasmuch as there is interaction between analogies - mental 
model; discussion - mental model; experimentation - mental model, and between various combinations of these stimuli and the mental model. The mental model change face arguments and information when they are being replaced or altered and the result is, a new mental model is created.

The stimulus that begins this development, when internal, is coming from a circumstantial change of environment, which creates an incentive to perception that something is not how it should be or that can be better. When it is external, the stimulus can occur through a lecture, training or simply a visit to another property.

Once the perception of change arises, the individual makes an analogy or comparison between the mental model suggested as a pattern and the result occurred or the potential result that was suggested by the change or the insight. Although the insight can have several origins, including discussion, information, feedback, at this moment, it has a specific aim, to improve the comprehension of the changes and to reduce uncertainty in activity; it can also occur as a result of interaction with technicians, other farmers, and collaborators of producers or own family.

The next step the experimentation can occur in the practice application of this new model; the learner searches for evidence to validate the new knowledge until a satisfactory new mental model emerges. This mental model will be last until the moment of another insight, when the cycle of production of knowledge will begin again.

\section{Final Considerations}

Knowledge creation, therefore, is initiated by some form of insight, internal or external. The old mental model undergoes alterations after being affected by the insight and continues the cycles in vary sequences and while being influenced, simultaneously, by discussion, experimentation and analogy. This continuously interaction will produce a mental model to satisfy the needs.

Then, as the cycle is developing, appropriate stimuli should be provided of the situation. These can take the form of courses, lectures, trainings, field days, discussions with technicians, visits, formal or informal reunions, controls, work with others or other learning opportunities. The information and insights gained from them are used by producers and serve as a "start" to create new knowledge, but they tend to stimulate new perceptions, because they activate and support future insights. They will be transformed into knowledge later by experimentation with this new background.

It is important to realize that people involved in the agricultural process can learn in different ways during this permanent process of change. The need of agribusiness - information, improvements, the best use of resources and the maximization of production - demand new behaviour. Another important aspect is that this learning is the result of the producers' desire improvements in their business and contribute to the agribusiness sector. It is also important to consider the cultural aspects of agribusiness to improve the learning. The research showed that the co-operative studied has a culture of learning and keeps strongly to this practice in its management, offering courses, lectures and others practices as quoted before.

Similarly, Nonaka and Takeuchi (1997) and Binotto and Nakayama (2001) agree that knowledge requires a positive attitude and human action to improve activities continuously. To Fleury and Fleury (2000) organizational learning involves not only forming new cognitive maps, but also and more importantly implementing new behaviours. It is possible to realize that the mental model only exists and has organizational validity from the moment it is internalised.

Considering these aspects, it's relevant to point out that the interactive cycle of change in the mental model does not necessarily obey the sequence described above. In some cases, one or more stages may be omitted; for example, the research showed that discussion and small experi- 
ments by producers, when they are successful, can change the mental model. The producers may even repeat stages before concluding the cycle.

One important point found in this research is that the cycle of learning develops by means of an interactive process of construction ending four phases that relate to each other. The process occurs through feedback and interconnection, the phases interacting among themselves, sequentially or otherwise, depending on the process desired or set in motion, associated with the specificity of the change.

This agrees with the emphasis of Nonaka and Takeuchi (1997) when they affirm that the model passes thought a series of changes of mental models, reinforcing the idea that the process is characterized as non-linear and interactive. Learning is an ongoing process including experiences or everything learned during life. It is a part of all the activities of human beings.

The model created in this research was developed in the specific reality of agribusiness and for particular purposes. It has some close relationships to the cycle of Kolb (1997), mainly when it comes to the constant and necessary interaction between action and reflection generating a continuous process.

Like Senge (1999), Kolb (1997) assumes that organizational learning is the sum of attributes of the people in the organization; this, in same ways, was not perceived in this research, which is supported, rather, by the statement of Kim (1993) that organizational learning is more complex and dynamic than the enlargement of individual learning. Similarly, the different styles of learning suggested by Kim were not significantly noticed in the research and they were not found to be decisive in the organizational knowledge creation process identified in this research.

The results of this research suggest ways in which the co-operatives studied, or other cooperatives can improve the knowledge creation process among agricultural producers. It would necessary to implemented several methods and/or instruments to generate and facilitate feedback from producers regarding improvements in activities, as well as common learning and teaching among them. This can create and improve the habit of socialization of knowledge, a fundamental step in creating the new knowledge.

Finally, as a suggestion is presented for the development of further research, based on this model, into two other aspects: the enabling conditions and the phases of the process of organizational knowledge creation, and search other ways of offering education and learning making use of different tools, considering the resources available in the different realities of agribusiness.

\section{References}

Argyris, C. (1992). Enfrentando desafios empresariais. (Facing managerial challenges). Rio de Janeiro: Campus. (in Portuguese).

Argyris, C. (2000). Ensinando pessoas inteligentes a aprender. (Teaching intelligent people to learn). Harvard Business Review. Knowledge Management. Rio de Janeiro: Campus. (in Portuguese).

Argyris, C. (2002). Double-loop learning, teaching, and research. Academy of Management Learning \& Education, 1 (2), $206-218$.

Argyris, C \& Schon, D. A. (1974). Theory in practice: Increasing professional effectiveness. San Francisco: Jossey-Bass.

Barney, J. B. (1986). Organizational culture: can it be a source of sustained competitive advantage? Academy of Management Review, Academy of Management. 11, 656-665.

Bedeian, A. G. (1986). Contemporary challenges in the study of organizations. Journal of Management, 12, 185-201. 
Bhatt, G. D. (2001). Knowledge management in organizations: Examining the interaction between technologies, techniques, and people. Journal of Knowledge Management, 5 (1), 68-75.

Bialoskorski, S. (1999). Brazilian workshop of management. Agri food systems. Ribeirão Preto. Sao Paulo. (in Portuguese)

Binotto, E. (2000). Os fatores comportamentais dos gestores das propriedades rurais na adoção das mudanças tecnológicas na produção da aveia branca no Rio Grande do Sul (The behavioural factors of rural properties management in adoption of technological changes in production of the white oat in Rio Grande do Sul). Master Dissertation.(Federal University of Rio Grande do Sul. Porto Alegre. Brasil), 107. (in Portuguese).

Binotto, E., \& Nakayama, M. K. (2001). Educação a distância no agronegócio sob a ótica das teorias da aprendizagem organizacional (Distance education in agribusiness under the optics of the theories of organizational learning). Brazilian Congress of Rural Management - ABAR, Goiânia. (in Portuguese).

Blum, R. (1999). Familiar agriculture: Preliminary study of classification diffusion and problematic. In J. C. Tedesco (Organizer), Agricultura familiar: Realidades e perspectives. (Familiar agriculture: Realities and perspectives). Passo Fundo: UPF. (in Portuguese).

Brazilian Ministry of Agricultural (n. d.) Retrieved Feb 20, 2004 from http://www.agricultura.gov.br (in Portuguese).

Davis, J.H., \& Goldberg, R. A. (1957). A concept of agribusiness. Boston: Division of Research. Graduate School of Business Administration. Harvard University.

Davenport, T. H., \& Prusak, L. (1998). Conhecimento Empresarial: Como as organizações gerenciam o seu capital intelectual. (Managerial knowledge: How the organization managers its intellectual capital). Rio de Janeiro: Campus. (in Portuguese).

Drucker, P. (1988). The coming of the new organization. Harvard Business Review, 66, 45-53.

Drucker, P. (1996). Administrando em tempos de grandes mudanças (Management in times of big changes). São Paulo: Pioneira. (in Portuguese).

Easterby-Smith, M , \& Araujo, L. (1999). Aprendizagem Organizaciona: Debates correntes e Oportunidades. (Organizational learning: Current debates and opportunities). In M. Easterby-Smith, L. Araujo, \& J. Burgoyne, Aprendizagem organizacional e organizaçôes de aprendizagem. (Organizational learning and the learning organization). (pp. 15 - 38) Sao Paulo: Atlas. (in Portuguese).

Edvinsson, L., \& Sullivan, P. (1996). Developing a model for managing intellectual capital. European Management Journal, 14 (4), 356-364.

Feiwel, G. R. (1975). The intellectual capital of Michal Kalecki: A study in economic theory and policy. Knoxville: University of Tennessee Press.

Fiol, C. M., \& Lyles, M. A. (1985). Organizational learning. Academy of Management Review, 10, 803 813.

Fleury, M. T. L., \& Fleury, A. (2000). Estratégias empresariais e formação de competências. (Managerial strategies and formation of competencies). São Paulo: Atlas. (in Portuguese).

Goerl, G. F. (1975). Knowledge management: cybernetics, professionalization, and knowledge management: An exercise in assumptive theory. Public Administration Review, 35. Blackwell Publishing Limited.

Haldin-Herrgard, T. (2000). Difficulties in diffusion of tacit knowledge in organizations. Journal of Intellectual Capital, 1 (4), 357-365.

Hamer, E., Binotto, E., \& Nakayama, M. K. (2003). The knowledge creation cycle on rural properties. IV International Conference on Agri-food Chain /Networks Economics and Management. Ribeirao Pretto,SP. 
Henry, N. (1975). Knowledge management: bureaucracy, technology, and knowledge management. Public Administration Review, 35, 572 - 578.

Howells, J. (1996). Tacit knowledge, innovation and technology transfer. Technology Analysis \& Strategic Management, 8 (2), 91.

Huber, G. P. (1991). Organizational learning: The contributing processes and the literatures. Organization Science, 2 (1), 88-115.

Hugon, P. (1984). História da doutrina econômica. (History of economic doctrines). São Paulo: Atlas. (in Portuguese).

Huysman, M. (2001). Contrabalançando tendenciosidades: Uma revisão crítica da literature sobre aprendizagem organizacional. (Compensating tendentiously: A critical revision of literature about organizational learning). In M. Easterby-Smith, J. Burgoyne, \& L. Araujo, Aprendizagem organizacional e organização de aprendizagem. (Organizational learning and organization of learning). (pp. 81 - 99). São Paulo: Atlas. (in Portuguese).

Kim, D. H. (1993). The link between individual and organizational learning. Sloan Management Review, $35(1), 37$ - 50.

Kogut, B., \& Zander, U. (1996). What firms do? Coordination, identity, and learning. Organization Science, 7 (5), 502- 518.

Kolb, D. (1997). A gestão e o processo de aprendizagem. (The management and the process of learning). In K. Starkey, Como as organizações aprendem How the organizations learn: relates of success of big companies. São Paulo: Futura. (in Portuguese).

Lam, A. (2000). Tacit knowledge, organizational learning and societal institutions: An integrated framework. Organization Studies, 21 (3), 487 - 513.

Lauschner, R. (1995). Agribusiness cooperative e produtor rural. (Agribusiness, co-operative and rural producer). São Leopoldo: Unisinos. (in Portuguese).

Leonard, D., \& Sensiper, S. (1998).The role of tacit knowledge in group innovation. California Management Review, Berkeley, 40 (3). 40-54.

Leroy, F., \& Ramanantsoa, B. (1997). The cognitive and behavioral dimensions of organizational learning in a merger: An empirical study. Journal of Management Studies, 34 (6), 871 - 894.

Marakas, G. M. (1999). Decision support systems in the twenty-first century. Upper Saddle River, NJ: Prentice Hall.

McCaffery, J. (1975). Knowledge management in fiscal policy formation. Public Administration Review, $35,598-602$.

Nelson, R. R., \& Winter, S. G. (1982). An evolutionary theory of economic change. Cambridge: Belknap Press of Harvard University Press.

Nonaka, I. (1991). The knowledge-creating company. Harvard Business Review, 69 (6), 96 - 103.

Nonaka, I. (1994). A dynamic theory of organizational knowledge creation. Organization Science, 5 (1), 14-37.

Nonaka, I., \& Konno, N. (1998). The concept of Ba: Building a foundation for knowledge creation. California Management Review, 40 (3), 40-54.

Nonaka, I., \& Reinmoeller, P. (2000). Dynamic business systems for knowledge creation and utilization. In C. Despres, \& D. Chauvel, Knowledge horizons : The present and the promise of knowledge management (pp. 89 - 112). Boston, Butterworth-Heinemann.

Nonaka, I.. Reinmoeller, P., \& Senoo, D. (1998). The 'ART' of knowledge: Systems to capitalize on market knowledge. European Management Journal, 16 (6), 673-684. 
Nonaka, I., Reinmoeller, P., \& Toyama, R. (2001). Integrated information technology systems for knowledge creation. In M. Dierkes, A. B. Antal, J. Child, \& I. Nonaka (Eds.), Handbook organizational learning and knowledge (pp. 827 - 848). Oxford: Oxford University Press.

Nonaka, I., \& Takeuchi, H. (1997). Criação do conhecimento na empresa: Como as empresas japonesas geram a dinâmica da inovação. (The knowledge-creation company: How the Japanese companies generate the dynamic innovation). Rio de Janeiro: Campus. (in Portuguese).

Nonaka, I., Toyama, R., \& Byosiere, P. (2001). A theory of organizational knowledge creation: Understanding the dynamic process of creating knowledge. In M. Dierkes, A. B. Antal, J. Child, \& I. Nonaka (Eds), Handbook organizational learning and knowledge (pp. 491 - 517). Oxford: Oxford University Press.

Nonaka, I., Toyama, R., \& Konno, N. (2000). SECI, ba and leadership: A unified model of dynamic knowledge creation. Long Range Planning, 33 (1), 5-34.

Nonaka, I., Umemoto, K., \& Senoo, D. (1996). From information processing to knowledge creation: A paradigm shift in business management. Technology in Society, 18 (2), 203-218.

Pawlowsky, P. (2001). The treatment of organizational learning in management science. In M. Dierkes, A. B. Antal, J. Child, \& I. Nonaka (Eds.), Handbook organizational learning and knowledge (pp. 61 88). Oxford, Oxford University Press.

Polany, M. (1967). The tacit dimension. Londres: Routledge \& Kegan Paul.

Prahalad, C. K., \& Hamel, G. (1990). The core competence of the corporation. Harvard Business Review, $68,79-91$.

Reinhardt, R., Bornemann, M., Pawlowsky, P., \& Schneider, U. (2001). Intellectual capital and knowledge management: Perspectives on measuring knowledge. In M. Dierkes, A. B. Antal, J. Child \& I. Nonaka (Eds.), Handbook organizational learning and knowledge (pp. 794 - 820). Oxford, Oxford University Press.

Robbins, S. P. (1999). Comportamento organizacional. (Organizacional behavioral). Rio de Janeiro: Livros Técnicos e Científicos Editora S.A. (in Portuguese)

Rosemberg, M. J. (2001). E-learning: Strategies for knowledge in the digital age. New York: McGrawHill.

Senge, Peter. (1999). A quinta disciplina (2 $2^{\mathrm{a}}$ ed.) (The fifth discipline). São Paulo: Best Seller. (in Portuguese).

Serenko, A., \& Bontis, N. (2004). Meta-review of knowledge management and intellectual capital literature: Citation impact and research productively rankings. Canada: Management of Innovation and New Technology Research Centre.

Shrivastava, P. (1983). A typology of organizational learning systems. Journal of Management Studies, 20, 7 - 28.

Silva, J. G. (1996). A nova dinâmica da agricultura brasileira (The new dynamic of Brazilian agriculture). São Paulo, Unicamp. (in Portuguese).

Spender, J.C. (2001). Gerenciando sistemas de conhecimento (Managing systems of knowledge). In M. T. L. Fleury, \& M. M. Oliveira Jr., Gestão estratégica do conhecimento: Integrando aprendizagem, conhecimento e competências. (Strategic Administration of Knowledge: Integrating Learning, Knowledge and Competencies). (pp. 27 - 49) São Paulo: Atlas. (in Portuguese).

Starbuck, W. H. (1992). Learning by knowledge-intensive firms. Journal of Management Studies. 29, 713 740.

Starkey, Ken. (1997) How organization learn. Sao Paulo: Futura, pp. 321-341. (in Portuguese).

Stewart, T. A. (1998). Capital intelectual - A nova vantagem competitive da empresa. (Intellectual capital: the novel competitive advantage of companies). Rio de Janeiro, Campus. (in Portuguese). 
Swieringa, J. , \& Wierdsma, A. (1995). La Organización que Aprende. Wilmington, USA: AddisonWesley.

Toffler, A. F. (1995). Powershift : O poder das mudanças (Powershift: The power of changes). Rio de Janeiro, Record. (in Portuguese).

Tripodi, T., Tony, F. P., \& Meyer, H. (1975). Análise da pesquisa social. (Analyse of Social Research). Rio de Janeiro: Record. (in Portuguese).

\section{Biographies}

Erlaine Binotto has pursued research in agribusiness during her masters and doctoral studies. She is a graduate in Administration, a specialist in education and holds masters degree in Agribusiness. Prior to that, she worked in an agricultural co-operative in Brazil as a supervisor in $\mathrm{Hu}$ man Resources. At present, she is a Post-Graduate Student of the Centre of Studies and Research in Agribusiness, at the Universidade Federal do Rio Grande do Sul, Brazil and she is developing her doctoral thesis as a PhD student in the School of Natural and Rural Systems Management at The University of Queensland, Australia. This stage of her research is funded by the Brazilian government through Coordenação de Aperfeiçoamento de Pessoal de Nível Superior (Capes). The research involves knowledge management and learning in a study with Brazilian and Australian agricultural producers, the former in are members of a co-operatives in Brazil and in latter without a co-operative in Australia.

Eleri Hamer is a Professor of the Faculdade do Sul do Mato Grosso, at the Centre of Teaching of Rondonópolis, Brazil, and he has a Masters Degree in Agribusiness from the Universidade Federal do Rio Grande do Sul, Brazil, where he developed research about knowledge creation. He is a graduate in Agronomy Engineering and a specialist in Rural Administration; he has worked for a number of years as a consultant to co-operatives and other companies in Total Quality programs and as general manager of the Sementes Girassol Company.

Marina Keiko Nakayama is a Doctor of Administration and Professor and Research in the School of Administration and Postgraduate studies in Agribusiness at the Universidade Federal do Rio Grande do Sul, Brazil. Previously, as a graduate in Psychology, with specialization in Human Resources, and a Masters degree in Administration, she worked in a company as a Human Resources Manager. She develops works linked to Human Resource Management as Consultant in Companies. Her areas of interest include knowledge management, learning, and distance education as well as virtuality in Human Resources. She has published many papers in different areas of research and chapters in several books.

Ricardo Azambuja Silveira is a professor and researcher of Computer Science at the Universidade Federal de Pelotas. His research interest is the design and the use of virtual relationship elearning and Distance Education in Human Resource Development. 